\title{
Isocyanate asthma: respiratory symptoms caused by diphenyl-methane di-isocyanate
}

\author{
A. R. TANSER, M. P. BOURKE, and A. G. B LANDFORD \\ St. Martin's Hospital, Bath and Shepton Mallet, Somerset
}

\begin{abstract}
Tanser, A. R., Bourke, M. P., and Blandford, A. G. (1973). Thorax, 28, 596-600. Isocyanate asthma: respiratory symptoms caused by diphenyl-methane di-isocyanate. We investigated 57 employees of a factory where diphenyl-methane di-isocyanate (MDI) was used to prepare the materials for making rigid polyurethane foam. Four employees had developed hypersensitivity to MDI. Two had severe, and one moderate asthma, while the fourth had symptoms resembling the delayed hypersensitivity type of reaction. Ten other employees had experienced unpleasant, mainly respiratory, irritant effects from MDI vapour.

A past history of bronchitis or of allergy was found more commonly in those with symptoms from MDI than in those without symptoms.

It is not known if MDI causes permanent damage to the respiratory tract. The most severely affected cases in the present series had normal spirometric values after recovery, and no persisting symptoms.

MDI is safer than other isocyanates used in industry but may cause both major and minor illness. It should be handled with the same precautions as those used with the more toxic compounds.
\end{abstract}

Isocyanates are chemicals used in the production of polyurethane products. The hazards of these substances are well known (Munn, 1965 ; Lancet, 1966) but some appear to be less toxic than others. Diphenyl-methane 4,41, di-isocyanate $\left[\mathrm{CH}_{2}\right.$ $\left(\mathrm{C}_{6} \mathrm{H}_{4} \mathrm{NCO}\right)_{2}$ or $\left.\mathrm{MDI}\right]$ is less volatile than other isocyanates commonly used in industry and has been considered to be of low toxicity (Munn, 1965).

In March 1971, two employees of a factory which prepared the chemicals needed to produce rigid polyurethane mouldings became ill after molten MDI was accidentally spilt in the factory. It appeared that all the employees were exposed to MDI vapour from time to time, and this prompted an investigation of all the staff.

\section{METHODS}

The factory was visited on two occasions at an interval of eight months. All the employees were examined on both occasions. At the first visit, 44 employees were interviewed after completing a questionnaire. Forced vital capacity (FVC) and forced expiratory volume in one second $\left(\mathrm{FEV}_{1}\right)$ were measured with a Vitalograph spirometer. Predicted normal values were obtained from the nomogram derived from the formula of
Cournand (Documenta Geigy Scientific Tables, 6th Edition, Basle, 1962).

On the second visit the same procedure was followed. Eight employees had left the factory, and there were 13 new employees, all of whom had been employed for at least three months. Thirty-six people were therefore re-examined, and a total of 57 were examined during the survey.

\section{RESULTS}

Fourteen of the 57 employees reported symptoms whenever they were in contact with MDI vapour (Table I). Three had severe symptoms, and their case histories are described below. One other employee had moderate but increasing tightness of the chest on repeated contact with MDI vapour. Another described wheezing, and others described tightness of the chest, headache, diarrhoea, or sore throat.

Twenty-six employees were in daily contact with MDI, and 12 of these noticed symptoms $(45 \%)$. The other 31 worked in offices or different parts of the factory, although all occasionally entered the building where MDI was used. Only two of these 31 complained of symptoms but one had severe symptoms (case 3 ). 
T A B LE I

DETAILS OF EMPLOYEES AFFECTED BY MDI

\begin{tabular}{|c|c|c|c|c|c|}
\hline Case & Sex & Age & $\begin{array}{c}\text { Risk of } \\
\text { Contact } \\
\text { with MDI }\end{array}$ & $\begin{array}{c}\text { History of } \\
\text { Possible } \\
\text { Allergy }\end{array}$ & Symptoms \\
\hline 1 & $\mathbf{M}$ & 27 & Frequent & Dermatitis & Severe \\
\hline 2 & $\mathbf{M}$ & 32 & Frequent & Dermatitis & Severe \\
\hline 3 & $\mathbf{M}$ & 46 & Occasional & Nil & $\begin{array}{l}\text { Fever, } \\
\text { myalgia, } \\
\text { dyspnoea }\end{array}$ \\
\hline 4 & $\mathbf{F}$ & 28 & Slight daily & Hay fever & $\begin{array}{l}\text { Increasing } \\
\text { tightness } \\
\text { of chest }\end{array}$ \\
\hline $\begin{array}{l}5 \\
6\end{array}$ & $\underset{\mathbf{M}}{\mathbf{F}}$ & $\begin{array}{l}65 \\
46\end{array}$ & $\begin{array}{l}\text { Slight daily } \\
\text { Frequent }\end{array}$ & $\begin{array}{l}\text { Nil } \\
\text { Asthma }\end{array}$ & $\begin{array}{l}\text { Wheezing } \\
\text { Tightness of }\end{array}$ \\
\hline 7 & $\mathbf{M}$ & 41 & Frequent & Nil & Tightness of \\
\hline 8 & $\mathbf{M}$ & 21 & $\begin{array}{l}\text { Moderate } \\
\text { daily }\end{array}$ & Nil & $\begin{array}{l}\text { Tightness of } \\
\text { chest }\end{array}$ \\
\hline 9 & $\mathbf{M}$ & 28 & Slight daily & Nil & $\begin{array}{l}\text { Tightness of } \\
\text { chest }\end{array}$ \\
\hline 10 & $\mathbf{M}$ & 24 & Slight daily & Nil & Tightness of \\
\hline 11 & $\mathbf{M}$ & 44 & Slight daily & Rhinitis & $\begin{array}{l}\text { Tightness of } \\
\text { chest }\end{array}$ \\
\hline 12 & $\mathbf{M}$ & 30 & Slight daily & Rhinitis & $\begin{array}{l}\text { Tightness of } \\
\text { chest }\end{array}$ \\
\hline 13 & $\mathbf{M}$ & 26 & Slight daily & Hay fever & $\begin{array}{l}\text { Headache, } \\
\text { diarrhoea }\end{array}$ \\
\hline 14 & $\mathbf{F}$ & 21 & Occasional & Nil & Sore throat \\
\hline
\end{tabular}

Severe symptoms-cases 1 to 3 ; moderately severe symptoms-cases 4 and 5 ; slight symptoms - cases 6 to 14

Forty-nine employees had an FVC of better than $90 \%$ predicted, with an $\mathrm{FEV}_{1} / \mathrm{FVC}$ ratio of $75 \%$ or more. Eight employees had results less good than this (Table II). Two of these complained of symptoms from MDI; six had no symptoms from this source.

\section{T A B L E I I}

SPIROMETRIC RESULT IN EMPLOYEES WITH FVC LESS THAN $90 \%$ PREDICTED OR FEV 1 FVC LESS THAN $75 \%$

\begin{tabular}{|c|c|c|c|c|c|c|}
\hline & \multirow[b]{2}{*}{ Age } & \multicolumn{2}{|c|}{ First Visit } & \multicolumn{2}{|c|}{ Second Visit } & \multirow[b]{2}{*}{ Notes } \\
\hline & & $\begin{array}{c}\% \\
\text { Predicted } \\
\text { FVC }\end{array}$ & $\begin{array}{c}\text { FEV }_{\text {I }} \\
\text { FVC }\end{array}$ & $\begin{array}{c}\% \\
\text { Predicted } \\
\text { FVC }\end{array}$ & $\begin{array}{c}\text { FEV } 1 \\
\text { FVC } \\
\%\end{array}$ & \\
\hline $\begin{array}{l}\text { Affected } \\
\text { by MDI }\end{array}$ & $\begin{array}{l}44 \\
65\end{array}$ & $\begin{array}{r}80 \\
101\end{array}$ & $\begin{array}{l}94 \\
64\end{array}$ & 80 & $\stackrel{94}{-}$ & $\begin{array}{l}\text { Smoker } \\
\text { Bronchitic }\end{array}$ \\
\hline $\begin{array}{l}\text { Not } \\
\text { affected } \\
\text { by MDI }\end{array}$ & $\begin{array}{l}17 \\
17 \\
23 \\
37 \\
52 \\
65\end{array}$ & $\begin{array}{l}\frac{86}{71} \\
\frac{69}{41}\end{array}$ & $\begin{array}{l}\frac{96}{87} \\
\frac{95}{55}\end{array}$ & $\begin{array}{l}85 \\
73 \\
69 \\
67 \\
43\end{array}$ & $\begin{array}{l}95 \\
85 \\
95 \\
85 \\
48\end{array}$ & $\begin{array}{l}\text { Smoker } \\
\text { Smoker } \\
\text { Smoker } \\
\text { Bronchitic } \\
\text { Bronchitic }\end{array}$ \\
\hline
\end{tabular}

Two cases were new employees at the second visit; two employees had left the firm.

There was no evidence of deterioration in the spirometric values of those retested after eight months. The results in the 12 people affected by MDI who were retested are given in Table III. Two affected employees were not retested. One woman of 65 retired shortly after the time of the first examination, and one employee affected by MDI had joined the factory after our first visit.
T A B L E I I I

RESULTS OF SPIROMETRY IN 12 EMPLOYEES AFFECTED BY MDI WHO WERE RETESTED AFTER 18 MONTHS

\begin{tabular}{|c|c|c|c|c|}
\hline \multirow{2}{*}{ Case } & \multicolumn{2}{|c|}{ First Visit } & \multicolumn{2}{|c|}{ Second Visit } \\
\hline & $\begin{array}{l}\% \text { Predicted } \\
\text { FVC }\end{array}$ & $\underset{\text { FVC } \%}{\text { FEV }_{1 /}}$ & $\begin{array}{l}\% \text { Predicted } \\
\text { FVC }\end{array}$ & $\begin{array}{c}\text { FEV } 1 \\
\text { FVC } \%\end{array}$ \\
\hline $\begin{array}{r}1 \\
2 \\
3 \\
4 \\
6 \\
8 \\
9 \\
10 \\
11 \\
12 \\
13 \\
14\end{array}$ & $\begin{array}{r}108 \\
107 \\
99 \\
117 \\
147 \\
101 \\
116 \\
104 \\
80 \\
115 \\
101 \\
101\end{array}$ & $\begin{array}{l}82 \\
80 \\
89 \\
77 \\
75 \\
80 \\
86 \\
89 \\
94 \\
82 \\
86 \\
93\end{array}$ & $\begin{array}{r}112 \\
104 \\
96 \\
120 \\
133 \\
98 \\
123 \\
104 \\
80 \\
112 \\
101 \\
109\end{array}$ & $\begin{array}{l}84 \\
78 \\
85 \\
80 \\
80 \\
81 \\
88 \\
89 \\
94 \\
84 \\
86 \\
95\end{array}$ \\
\hline ean & 108 & 84 & 108 & 85 \\
\hline
\end{tabular}

Thirteen employees had a past history of possible allergic symptoms (Table IV). Eight were in daily contact with MDI and seven of these had symptoms from it (Table V).

Thirty-nine employees had a past history of bronchitis. Nineteen of these were in potential daily contact with MDI, and 10 of these $(53 \%)$ had symptoms from it.

T A BLE I V

EMPLOYEES GIVING A HISTORY OF POSSIBLE ALLERGY

\begin{tabular}{|c|c|c|c|c|c|}
\hline \multicolumn{4}{|c|}{ Nature of Allergy } & \multirow{2}{*}{$\begin{array}{c}\text { No. } \\
\mathbf{5} \\
\mathbf{3} \\
\mathbf{3} \\
\mathbf{2}\end{array}$} & \multirow{2}{*}{$\begin{array}{l}\text { Affected by MDI } \\
2 \text { (cases } 1 \text { and } 2 \text { ) } \\
2 \text { (cases } 5 \text { and } 11) \\
2 \text { (cases } 12 \text { and 13) } \\
1 \text { (case 6) }\end{array}$} \\
\hline $\begin{array}{l}\text { Dermatitis } \\
\text { Perennial } \\
\text { Hay fever } \\
\text { Asthma }\end{array}$ & $\begin{array}{l}\text { rhinitis } \\
\ldots \\
\ldots\end{array}$ & $\begin{array}{l}\ddot{*} \\
\ddot{*}\end{array}$ & $\begin{array}{l}\ldots \\
\ldots \\
\cdots\end{array}$ & & \\
\hline Total & .. & .. & .. & 13 & 7 \\
\hline
\end{tabular}

T A B LE V

PREEXISTING SYMPTOMS IN GROUP IN POTENTIAL DAILY CONTACT WITH MDI

\begin{tabular}{|c|c|c|}
\hline & & Affected by MDI \\
\hline Total number in daily contact & 26 & $12 / 26(46 \%)$ \\
\hline $\begin{array}{l}\text { Previous bronchitis } \\
\text { No previous bronchitis }\end{array}$ & $(P>0.02)^{19}$ & $\begin{array}{c}10 / 19(53 \%) \\
2 / 7(28 \%)\end{array}$ \\
\hline $\begin{array}{l}\text { Possible allergy } \\
\text { No history of allergy }\end{array}$ & $(P>0.01)^{18}$ & $\begin{array}{l}7 / 8(88 \%) \\
5 / 18(28 \%)\end{array}$ \\
\hline
\end{tabular}

\section{CASE HISTORIES}

CASE 1 Mr. B. J. P., aged 26, was originally employed at another factory as an electrician helping to assemble the machinery for the production of polyurethane, and concerned specifically with the design of the heat exchanger. He noticed that exposure to spilt MDI caused constipation and abdominal pain. In the present factory he dismantled a heat exchanger without wear- 
ing a respirator and came into contact with molten MDI and MDI vapour. This caused wheezing. Subsequently contact with MDI caused severe wheezing lasting from 45 minutes to 2 hours, relieved by isoprenaline inhalation. He had been affected outside the factory when standing near the extractor fan. He had also noticed slight wheezing when using polyurethane paints. He was a non-smoker, although colds usually caused 'bronchitis'. He had suffered minor dermatitis of the hands in the past but did not know the cause. There was no other personal or family history of allergy. Skin tests to seven common allergens were negative. FVC was $4,750 \mathrm{ml}\left(105 \%\right.$ predicted), $\mathrm{FEV}_{1}$ $4,000 \mathrm{ml}, \mathrm{FEV}_{1} / \mathrm{FVC}=84 \%$.

CASE 2 Mr. E. J. D., aged 33, was employed using the machine in which MDI and resin were mixed. He was exposed to some MDI every working day. After working at the factory for three weeks he complained of dyspnoea and wheezing. He was a cigarette smoker who had had attacks of bronchitis in the past, but on no previous occasion had he been wheezy. He had suffered from allergic dermatitis when working in a bakery. When first seen by one of us (A. G. B.) he was wheezing, with a peak flow rate measured on a Wright peak flow meter of $2001 . / \mathrm{min}$. He was treated with choline theophyllinate. Two days later his peak flow rate was $4101 . / \mathrm{min}$, later increasing to $4501 \mathrm{l} / \mathrm{min}$.

He returned to work in another part of the factory but found that occasional contact with MDI again caused him to become wheezy. Treatment with disodium cromoglycate was started, and he then found that slight contact with MDI no longer caused noticeable symptoms, although he still occasionally became wheezy. His FVC and FVC/ $\mathrm{FEV}_{1}$ were normal when he was free from symptoms.

CASE 3 Mr. E. G.S., aged 46, had been employed for 14 months as a chemist but was not himself using isocyanates. Shortly after MDI was first used in the factory he developed a feverish illness with headache, cough, and aching limbs. He recovered within three days. Subsequently he felt well each morning, but if the factory was using MDI he would feel unwell during the afternoon and evening. He felt feverish, would lose his voice, develop a headache and cough and moderate dyspnoea. This occurred about three times a week for six weeks, with apparent increasing severity. At this stage he realized the circumstances which were causing him to feel ill and kept out of the factory. On four subsequent occasions he did come into contact with MDI, and on each occasion the same symptoms developed and lasted about 48 hours.

There was no history of allergy, although his son had hay fever. He did not smoke but sometimes had bronchitis with 'colds'. Skin tests to seven common allergens were negative. FVC was $3,600 \mathrm{ml}(96 \%$ predicted), $\mathrm{FEV}_{1} 3,050 \mathrm{ml}, \mathrm{FEV}_{1} / \mathrm{FVC}=85 \%$.

CASE 4 One man complained of moderate but increasingly severe wheezing after contact with spilt MDI.

CASES 5 to 12 Eight people complained of tightness of the chest after contact with MDI vapour. All but one were explicit that they did not wheeze.

CASES 13 and 14 One person complained of headaches and slight diarrhoea, and one of sore throats after contact with spilt MDI.

\section{DISCUSSION}

Isocyanates react with a wide variety of compounds containing active hydrogen atoms. Compounds containing hydroxyl groups readily form esters of $\mathrm{\infty}$ substituted carbamic acid (urethanes), and the name if 'polyurethane' has become accepted as a generic oै

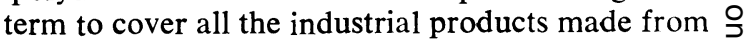
isocyanates (Buist, 1970). The isocyanates most $\vec{c}$ widely used in industry are the di-isocyanates - $D$ tolylene di-isocyanate (TDI) and diphenyl-methane di-isocyanate (MDI). The hazards of isocyanates have been widely reported (Lancet, 1966), but most $\bar{\Phi}$ reports have been concerned with the effects of the more toxic TDI. This has been shown to cause a fall in $\mathrm{FEV}_{1}$ in concentrations well below the $\omega$ threshold limit value of 0.02 parts per million (Peters, Murphy, Pagnotto, and van Ganse, 1968). Continued exposure to low concentrations of TDI may also cause cumulative changes of this nature (Peters, Murphy, and Ferris, 1969 ; Adams, 1970).

In the present study, the concentrations of MDI to which individual workers were exposed were not known. The vapour pressure of solid MDI is low (Munn, 1970), but splashes or a spray of molten MDI may allow the inhalation of droplets. Respiratory symptoms may occur from a direct irritant effect of MDI, and occasional cases of $\stackrel{\vec{x}}{x}$ sensitization have been reported (Longley, 1964 ; Munn, 1965).

We found that $45 \%$ of workers frequently ex- $\delta$ posed to MDI had observed toxic effects from it. 3 In most cases these effects appeared to be those of an irritant, mainly affecting the respiratory system and causing what was described as 'tightness of the chest'. We found no evidence of permanent deterioration, judged by spirometry, during a $\mathscr{S}$ period of eight months.

However, four people (29\%) gave histories which N suggested that they had developed hypersensitivity 0 to MDI (cases 1 to 4 ). In three cases $(1,2$, and 4) asthma was precipitated by contact with MDI, and in one case the asthma was severe and could be caused by concentrations of MDI which could not 7 be detected by available instruments. The wheezing responded to bronchodilators, and in the one patient in whom it was tried (case 2) di-sodium cromoglycate appeared to afford some protection.

In one patient with severe symptoms (case 3), the reaction was not that of asthma but of symp- 
toms resembling those of the delayed hypersensitivity type of reaction such as may occur with certain organic dusts, as in 'farmer's lung'. The symptoms were of such severity that the patient, quite rightly, refused to go anywhere near MDI. This type of reaction to MDI has not been described before.

The immunology of hypersensitivity reactions to isocyanates has not been fully explained. Circulating antibodies have been detected in individuals sensitive to TDI (Taylor, 1970), but Konzen, Craft, Scheel, and Gorski (1966) failed to induce hypersensitivity or find circulating antibodies using MDI, although Stevens (1967) showed that MDI caused cutaneous hypersensitivity in albino guineapigs as readily as TDI. There are considerable technical difficulties in pursuing this type of investigation, and the clinical evidence for the occurrence of hypersensitivity to TDI and MDI is considerable. The present study suggests that both immediate and delayed hypersensitivity may occur with exposure to MDI.

\section{PREDISPOSING FACTORS AND PREVENTIVE MEASURES}

Twelve of the 14 people affected by MDI had daily contact with it in that they worked in parts of the factory where MDI was used. One of the two who had only occasional contact had severe symptoms (case 3). He had no previous history of allergy but was subject to bronchitis. The other employee with infrequent contact with MDI complained of only mild symptoms, mainly sore throat. There were no apparent predisposing factors.

Of those in daily contact with MDI, $73 \%$ had a history of previous bronchitis ; $53 \%$ of these developed symptoms from MDI, and only $28 \%$ of those without a history of bronchitis noticed symptoms (Table V). These figures suggest an association but are not statistically significant. Previously, a history of bronchitis has been found to predispose to symptoms from TDI (Peters, 1970). Eight people had a history of 'allergy' (Tables IV and V); seven of these were affected by MDI $(88 \%)$ as compared to $28 \%$ of the 18 without such a history. This association is statistically significant, but the clinical significance is less obvious since only two of the seven affected had hypersensitivity, the others suffering only irritant effects.

Until more information is available, it seems advisable that employees with a history of allergy or bronchitis should not come into contact with MDI.
It is not known whether repeated exposure to MDI vapour will cause permanent respiratory damage, as may occur with exposure to TDI, but there is no justification for allowing any employee to run this risk. Similar precautions should be used when handling molten MDI as when handling TDI, and methods adapted to the individual factory should minimize the risk of spillage and splashing. When the factory we studied first used MDI, the drums of solid material were warmed with a heat cradle so that the MDI could be pumped into the reaction chambers. When the hose was withdrawn from the empty drums, splashes of molten MDI falling on the heating element may have given rise to locally high concentrations of vapour. This was changed to warming the drums in a water bath to avoid this risk. Areas where spillage may occur should be enclosed and provided with effective exhaust ventilation. Dismantling defective machinery and removing spilt MDI should only be carried out by staff wearing effective respirators, preferably forced-air hoods. The present threshold limit value for MDI and TDI, set by the American Conference of Industrial Hygienists in 1969 was 0.02 parts per million $(0.2$ $\mathrm{mg} / \mathrm{m}^{3}$ ), but further experience will indicate if this level is acceptable and safe.

Although MDI is undoubtedly safer than TDI, the fact that it may cause severe reactions due to the development of hypersensitivity does not appear to be generally appreciated. Since becoming aware of this possibility, one of us (A. R.T.) has been approached by two other firms producing rigid polyurethane foam for advice as to simple precautions to take when handling MDI. These firms had not previously been aware that there was any significant potential hazard to health. We discussed the use of MDI with a sales engineer concerned solely with equipment for producing rigid polyurethane foam products, and he described extremely careless handling of molten MDI, particularly in certain North American factories. He had experienced severe irritant effects lasting two or three weeks but did not appear to have developed hypersensitivity.

We believe that our experience has confirmed that there is a significant hazard from MDI, but that this can be controlled if the correct precautions are taken.

We wish to thank Miss H. Gimblett for invaluable technical assistance, and to express our appreciation of the willing co-operation of the manager and personnel of the factory involved. 


\section{REFERENCES}

Adams, W. G. F. (1970). Lung function of men engaged on the manufacture of tolylene diisocyanate (TDI). Proceedings of the Royal Society of Medicine, 63, 378.

Buist, J. M. (1970). Isocyanates in industry. Proceedings of the Royal Society of Medicine, 63, 365.

Konzen, R. B., Craft, B. F., Scheel, L. D., and Gorski, C. H. (1966). Human response to low concentrations of $\mathrm{p}$, p-diphenylmethane diisocyanate (MDI). American Industrial Hygiene Association Journal, 27, 121.

Lancet (1966). Hazards of di-isocyanates. 1, 32.

Longley, E. O. (1964). Methane diisocyanate; a respiratory hazard? Archives of Environmental Health, 8, 898.

Munn, A. (1965). Hazards of isocyanates. Annals of Occupational Hygiene, 8, 163.

- (1970). Contribution to Symposium on isocyanates. Proceedings of the Royal Society of Medicine, 63, 372.
Peters, J. M. (1970). Cumulative pulmonary effects in workers exposed to tolylene diisocyanate. Proceedings of the $\overline{\bar{M}}$ Royal Society of Medicine, 63, 372.

Murphy, R. L. H., and Ferris, B. G. (1969). Ventilatory function in workers exposed to low levels $\%$ of toluene diisocyanate: a six-month follow-up. BritishJournal of Industrial Medicine, 26, 115.

$\longrightarrow,-$ Pagnotto, L. D., and van Ganse, W. F. (1968). $\overrightarrow{\vec{\omega}}$ Acute respiratory effects in workers exposed to low

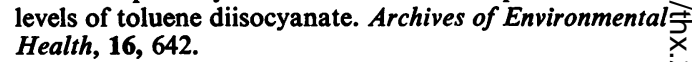

Stevens, M. A. (1967). Use of the albino guinea-pig to detectoo the skin-sensitizing ability of chemicals. British Journalir of Industrial Medicine, 24, 189.

Taylor, G. (1970). Immune responses to tolylene diisocyanate (TDI) exposure in man. Proceedings of the $\triangle$ Royal Society of Medicine, 63, 379. 